\title{
Biodiversity, Distribution and Taxonomy of Conidial Fungus Corynespora (Corynesporascaceae) Associated With Malvaceae
}

\section{Kumar $\mathbf{S}^{1 *}$ and Singh $\mathbf{R}^{2}$}

${ }^{1}$ Department of Forest Pathology, Kerala Forest Research Institute, Peechi-680653, Kerala, India

${ }^{2}$ Centre of Advanced Study in Botany, Institute of Science, Banaras Hindu University, Varanasi-221005, Uttar Pradesh, India

\begin{abstract}
This paper deals the biodiversity, distribution and taxonomy of conidial fungus Corynespora associated with family Malvaceae, including a new species belonging to the genus Corynespora, viz. C. sidae sp. nov., was discovered on living leaves of Sida acuta Burm.f. (Malvaceae) from University Campus of Deen Dayal Upadhyay Gorakhpur University, Gorakhpur, Uttar Pradesh (UP), India. This species is described, illustrated and compared with similar taxa reported on Malvaceae based on morphological characters. The novel species is characterized by shorter conidiophores and longer and smooth conidia. The nomenclatural novelties were submitted in Mycobank.
\end{abstract}

Keywords: Anamorphic fungi; Morphotaxonomy; Malvaceae; Corynespora

\section{Introduction}

The foliicolous hyphomycetous genus Corynespora was established by Gussow [1]. The genus causes foliar diseases in plants, predominating in the tropics and subtropics regions including India, is characterized by producing distoseptate conidia with or without distinct hila and monoblastic, terminal conidiogenous cells. Most of the species of the genus are phytopathogenic while some species are reported as endophytes and saprobes. About 135 species of Corynespora have been reported from all over the world [2-4].

In the continuation of exploration of foliicolous fungi from eastern Uttar Pradesh, a species rank of the genus Corynespora was found to be hitherto undescribed. The detail descriptions and illustrations of Corynespora sidae are presented here in this communication

\section{Material and Methods}

Plant specimens with clear visible disease symptoms of parasitic fungi on living leaves were collected from University Campus of Deen Dayal Upadhyay (DDU) Gorakhpur University, Gorakhpur (26' 44" to 56.23" N and 83' 23" to 31"E), Uttar Pradesh. The samples were placed in separate polyethylene bags and transported to the laboratory and processed by following the standard techniques $[5,6]$. The sun dried and pressed leaf specimens were placed in air tight polyethylene bags and then kept in paper envelops along with collection details. Photographs of infection spots on host leaves were taken by using a Sony DSC-5730 camera. The specimens for microscopic observation were prepared by hand sectioning and scraping. Morphological descriptions are based on the slide preparations mounted on clear lacto-phenol cotton blue mixture from infected areas of the leaves. Observations were made with an Olympus BX-51 light microscope. Detailed observations of morphological characters and line drawings were carried out at different magnification through a light microscope $(400 \times$ and $1000 \times)$. Measurements were made of 30 conidia, hila, and conidiophores, with the extremes given in parentheses. Morphotaxonomic determinations were made with the help of current literature. The type specimen has been deposited in the Ajrekar Mycological Herbarium (AMH), Agharkar Research Institute (ARI), Pune, Maharashtra (MS), India; and a part of the same were retained in the mycological herbarium of Birbal Sahni Institute of Palaeobotany (BSIPMH), Lucknow for future reference. The details of Description and nomenclatural novelties were deposited in MycoBank (www.MycoBank.org). The systematics of the taxon is given in accordance with given literatures [2,3,7-11].

\section{Results}

Corynespora sidae Sham. Kumar \& Raghv. Singh, sp. Nov (Figures 1-3).

\section{MycoBank: MB 816950}

Etymology: Named after the host genus upon which it occurs. Anamorphic fungi, Hyphomycetes, Foliicolous, infection spots amphigenous, circular to sub-circular to irregular, 5-7 $\mathrm{mm}$ in diameter, concentric, dark brown to blackish. Colonies amphiphyllous, effuse and grayish. Mycelium internal.

\section{Sexual morph: undetermined.}

Asexual morph: Stromata absent. Conidiophores macronematous, mononematous, cylindrical, erect to procumbent, straight to flexuous, unbranched, smooth, thick-walled, 1-3-septate, mid brown, 80-165×5-

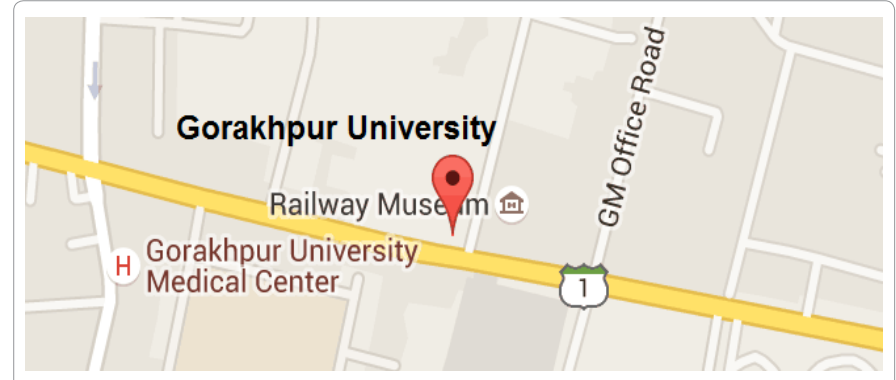

Figure 1: Location map (source: https://www.google.co.in)

*Corresponding author: Kumar S, Department of Forest Pathology, Kerala Forest Research Institute, Peechi 680653, Kerala, India, Tel: +919935110159; E-mail: skumartaxon@gmail.com

Received May 30, 2016; Accepted August 18, 2016; Published August 25, 2016

Citation: Kumar S, Singh R (2016) Biodiversity, Distribution and Taxonomy of Conidial Fungus Corynespora (Corynesporascaceae) Associated With Malvaceae. J Biodivers Endanger Species 4: 166. doi: 10.4172/2332-2543.1000166

Copyright: $\odot 2016$ Kumar S, et al. This is an open-access article distributed under the terms of the Creative Commons Attribution License, which permits unrestricted use, distribution, and reproduction in any medium, provided the original author and source are credited. 
Citation: Kumar S, Singh R (2016) Biodiversity, Distribution and Taxonomy of Conidial Fungus Corynespora (Corynesporascaceae) Associated With Malvaceae. J Biodivers Endanger Species 4: 166. doi: 10.4172/2332-2543.1000166

$10 \mu \mathrm{m}$, basal cell swollen. Conidiogenous cells integrated, terminal, monotretic, scars unthickened. Conidia acrogenous, dry, solitary, unbranched, thin-walled, smooth, straight to curved, usually obclavate to obclavate-cylindrical, 2-24-distoseptate with $0-1$ transverse band like eusepta, $25-220 \times 7-17 \mu \mathrm{m}$, apex obtuse to rounded, olivaceous to very light brown, hilum thickened, 3.5-4.5 $\mu \mathrm{m}$ wide.

Type: India, Uttar Pradesh, DDU Gorakhpur University, University Campus, on living leaves of Sida acuta Burm.f. (Malvaceae), 10th December 2006, Coll., Shambhu Kumar, AMH-9706 (holotype), BSIPMH-050 (isotype).

Teleomorphs: not found.

\section{Discussion}

C. cassiicola, C. hibisci and Corynespora sp. have been reported on family Malvaceae. C. cassicola was reported from different corners of the world on different host of family Malvaceae viz., Abelmoschus esculentus (L.) Moench from Brunei Darussalam [12,13]; Gossypium barbadense L. from Barbados [14]; Gossypium hirsutum L. from Alabama [15], Georgia [16], India [17,18]; Hibiscus cannabinus L. from Papua New Guinea [19]; Abelmoschus esculentus (L.) Moench (=Hibiscus esculentus L.) from Cuba [20], Ghana [21], Sierra Leone [22]; Hibiscus mutabilis L. from Korea [23,24]; Hibiscus sabdariffa L. from Sierra Leone [22]; Hibiscus sp. from Cuba (Urtiaga, 2004) [20]; Hibiscus syriacus L. from Korea [25]; Pavonia sp. from Venezuela [26]; Sida glomerata Cav. from Venezuela [26]; Sida rhombifolia L. from Myanmar [13], Venezuela [27] and C. hibisci was reported on Hibiscus syriacus L. from Japan [28] while Corynespora sp. Alcea sp. [29] and Malvaviscus sp. [30] from Florida (was similar to C. cassicola). Therefore the present fungus is compared with closely similar species C. cassiicola and C. hibisci for novelty.

From Table 1, it is clear that the conidiophores of $C$. sidae is shorter and having less septa than C. cassiicola $(110-850 \times 7.5-10 \mu \mathrm{m}$, upto 9 successive proliférations septate) and C. hibisci $(98-291 \times 4-11 \mu \mathrm{m}$,
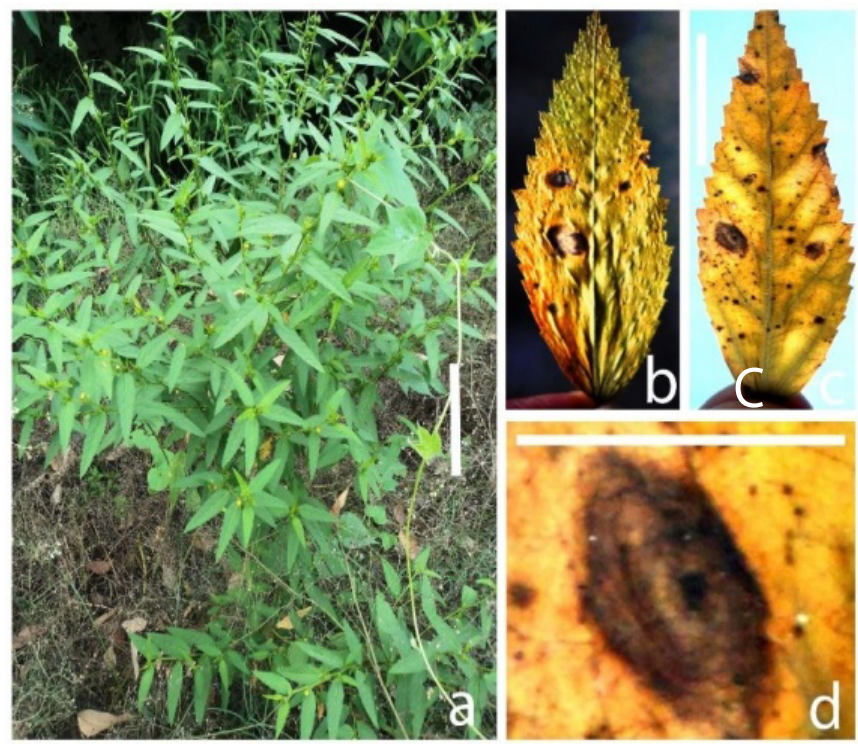

Figure 2: (a) Sida acuta L. (holotype AMH-9706).

(b) Symptom on lower surface.

(c) Symptom on upper surface.

(d) Symptom enlarges view. Scale bars: $a-d=20 \mathrm{~mm}$.

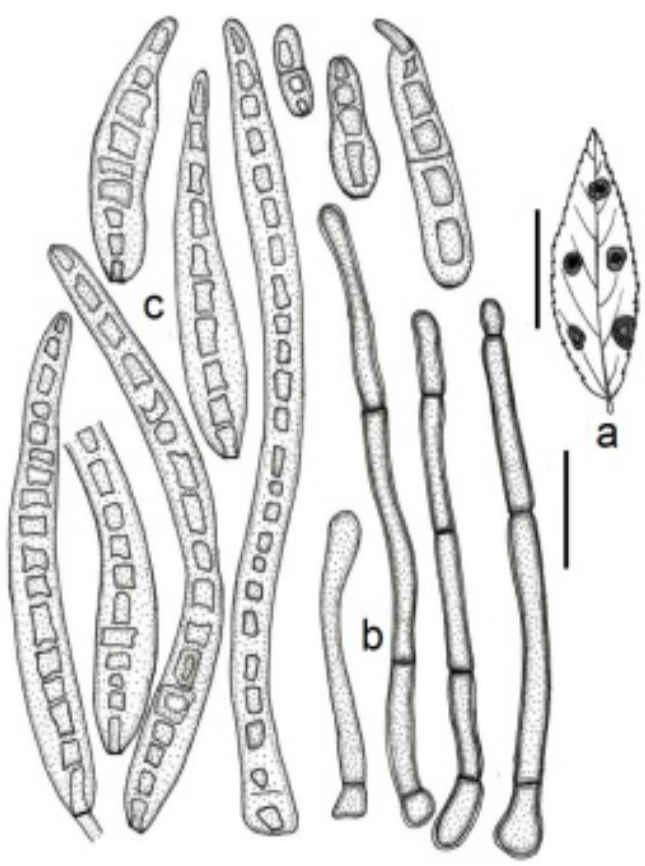

(a) Infection spot, (b) conidiophores, (c) conidia. Scale bars: a=20 mm, $\mathrm{b}, \mathrm{c}=20 \mu \mathrm{m}$.

Figure 3: Corynespora sidae Lucida Drawing (holotype AMH-9706).

\begin{tabular}{|c|c|c|}
\hline $\begin{array}{c}\text { Corynespora } \\
\text { spp. }\end{array}$ & Conidiophores & Conidia \\
\hline C. cassiicola & $\begin{array}{c}110-850 \times 7.5-10 \mu \mathrm{m}, \text { upto } \\
9 \text { successive proliférations } \\
\text { septate }\end{array}$ & $\begin{array}{c}40-220 \times 4-8 \mu \mathrm{m}, \\
4-20 \text {-distosepta }\end{array}$ \\
\hline C. hibisci & $98-291 \times 4-11 \mu \mathrm{m}$, & $75-185 \times 15-22.5 \mu \mathrm{m}$, \\
& $5-6-$ septate & $3-16$-distosepta \\
\hline C. sidae & $80-165 \times 5-10 \mu \mathrm{m}$, & $25-220 \times 7-17 \mu \mathrm{m}$, \\
& $1-3-$ septate & $7-23$-distosepta \\
\hline
\end{tabular}

Table 1: Comparison of $C$. sidae with C. cassiicola and C. hibisci.

5-6-septate). The conidia of C. sidae are comparatively shorter and thicker than C. cassicola $(40-220 \times 4-8 \mu \mathrm{m}, 4-20$-distosepta $)$ and longer, thinner and having more distosepta than C. hibisci (75-185 $\times 15-22.5 \mu \mathrm{m}, 3-16$-distosepta). Therefore, based on comparative analyses the present collection is treated as a new species s.

\section{Acknowledgement}

We are much obliged to the Director, Kerala Forest Research Institute, Peech for encouragement and the Head, Centre of Advanced Study in Botany, Banaras Hindu University, Varanasi for necessary facilities. Thankfulness is also due to Curator, AMH-ARI, and Pune for providing accession number of the type specimen. The authors' are also thankful to the reviewer for their significant contributions to improving the manuscript. Financial assistance (SB/YS/LS-288/2013) to the first author (SK) by SERB, DST, Government of India, New Delhi is very much acknowledged.

\section{References}

1. Güssow HT (1906) Über eine neue Krankheit an Gurken in England. Zeitschrift für Pflanzenkrankheiten und Pflanzenschutz. 16:10-13.

2. Farr DF, Rossman AY (2016) Fungal Databases, Systematic Mycology and Microbiology Laboratory, ARS, USDA.

3. Index Fungorum (2016) Index Fungorum, CABI, CBS and Landcare Research (custodians), accessed 15 April 2016. 
Citation: Kumar S, Singh R (2016) Biodiversity, Distribution and Taxonomy of Conidial Fungus Corynespora (Corynesporascaceae) Associated With Malvaceae. J Biodivers Endanger Species 4: 166. doi: 10.4172/2332-2543.1000166

Page 3 of 3

4. MycoBank (2016) MycoBank (Fungal databases nomenclature and species banks), accessed 15 April 2016.

5. Hawksworth DL (1974) Mycologist's Handbook. Commonwealth Mycological Institute, Kew $231 \mathrm{p}$.

6. Savile DBO (1962) Collection and care of Botanical specimens. Canadian Department of Agriculture, Publication, Research Branch 1113: 1-124.

7. Ellis MB (1971) Dematiaceous Hyphomycetes, Commonwealth Mycological Institute, Kew, England 608 p.

8. Ellis MB (1976) More Dematiaceous Hyphomycetes, Commonwealth Mycological Institute, Kew, England 507 p.

9. Cannon PF, Kirk PF (2007) Fungal Families of the World. Wallingford, UK: CAB International $456 \mathrm{p}$.

10. Kirk PF, Cannon PF, Minter DW, Stalpers JA (2008) Dictionary of the Fungi. 10th ed. Wallingford, UK: CAB International $784 \mathrm{p}$.

11. Seifert K, Morgan JG, Gams W, Kendrick B (2011) The Genera of Hyphomycetes. CBS Biodiversity Series 9: 1-997.

12. Peregrine WTH, Ahmad KB (1982) Brunei: A first annotated list of plant diseases and associated organisms. Phytopathol Pap 27: 1-87.

13. Urtiaga R (2004) Indice de enfermedades en plantas de Venezuela y Cuba, Second Edition. Unknown journal or publisher: 301p.

14. Norse D (1974) Plant Diseases in Barbados. Phytopathol Pap 18: 1-38.

15. Conner KN, Hagan AK, Zhang L (2013) First Report of Corynespora cassiicolaIncited Target Spot on Cotton in Alabama. Plant Dis. 97: 1379.

16. Fulmer AM, Walls JT, Dutta B, Parkunan V, Brock J, Kemerait Jr, RC (2012) First Report of Target Spot Caused by Corynespora cassiicola on Cotton in Georgia. Plant Dis 96: 1066.

17. Sarbhoy, AK, Lal G, Varshney JL (1971) Fungi of India. Navyug Traders, New Delhi pp 148.
18. Lakshmanan $P$, Jeyarajan R, Vidhyasekaran $P$ (1990) A boll rot of cotton caused by Corynespora cassiicola in Tamil Nadu, India. Phytoparasitica 18: 171-173.

19. Shaw DE (1984) Microorganisms in Papua New Guinea. Dept. Primary Ind., Res. Bull 33: 1-344.

20. Urtiaga R (1986) Indice de enfermedades en plantas de Venezuela y Cuba Impresos en Impresos Nuevo Siglo. S.R.L, Barquisimeto, Venezuela 202 p.

21. Hughes SJ (1952) Fungi from the Gold Coast. I. Mycol. Pap 48: 1-91.

22. Wei CT (1950) Notes on Corynespora. Mycol. Pap 34: 1-10.

23. Kwon JH, Park CS (2003) Leaf spot of cotton rose caused by Corynespora cassiicola in Korea. Mycobiology 31: 57-59.

24. Cho WD, Shin HD (2004) List of plant diseases in Korea. 4th edn. KSPP pp 779.

25. Seo ST, Park JH, Cho SE, Shin HD (2013) First Report of Leaf Spot Caused by Corynespora cassiicola on Rose of Sharon in Korea. Plant Dis 97: 847.

26. Urtiaga R (2004) Host index of plant diseases and disorders from Venezuela Addendum. Unknown journal or publisher: 268p.

27. Thaung MM (2008) A list of hypomycetes (and agonomycetes) in Burma Australas. Mycol 27: 149-172.

28. Kobayashi T (2007) Index of fungi inhabiting woody plants in Japan. Host Distribution and Literature. Zenkoku-Noson-Kyoiku Kyokai Publishing Co., Ltd. $1227 \mathrm{p}$.

29. Alfieri Jr, SA, Langdon KR, Wehlburg C, Kimbrough JW (1984) Index of Plant Diseases in Florida (Revised). Florida Dept. Agric. and Consumer Serv., Div. Plant Ind. Bull 11: 1-389.

30. Miller JW (1991) Bureau of Plant Pathology. Tri-ology Techn. Rep. Div. PI. Indust., Florida 30: 3-5. 